\title{
Investigating Hepatitis C, D and HIV Prevalance in Cases with Positive Hepatitis B Virus Antigen in a Tertiary Hospital and Examining Anti-HDV Positive Cases
}

\author{
Üçüncü Basamak Bir Hastanede Hepatit B Virüsünün Yüzey Antijeni Pozitif Olgularda \\ Hepatit C, D ve HIV Sıklığının Araștırılması ve Anti-HDV Pozitif Olguların İrdelenmesi
}

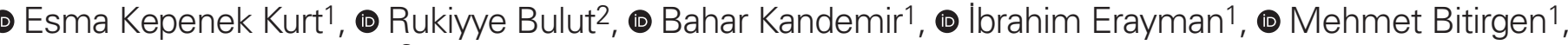
(D) Fatma Esenkaya Taşbent ${ }^{3}$

\footnotetext{
${ }^{1}$ Necmettin Erbakan University, Meram Faculty of Medicine, Department of Infectious Diseases and Clinical Microbiology, Konya, Turkey

2Gümüşhane State Hospital, Clinic of Infectious Diseases and Clinical Microbiology, Gümüşhane, Turkey

${ }^{3}$ Necmettin Erbakan University, Meram Faculty of Medicine, Department of Medical Microbiology, Konya, Turkey
}

\begin{abstract}
Objectives: Hepatitis B infection has a faster and more progressive course in the presence of hepatitis $\mathrm{C}$ virus (HCV), HDV and human immunodeficiency virus (HIV) infections. The aim of this study was to determine anti-HCV, anti-HDV and anti-HIV prevalance in hepatitis B surface antigen ( $\mathrm{HBsAg})(+)$ positive patients and to examine patients with positive anti-HDV.

Materials and Methods: Data were obtained through scanning hepatitis B patient follow-up files and the hospital automation system. Descriptive data was expressed in numbers and percentages (\%). Results: Mean age of $1829 \mathrm{HBsAg}$ positive patients was $42.65 \pm 14.83$ (7-95) and 1099 (60.1\%) were male and 730 (39.9\%) were female. 30 patients $(1.64 \%)$ had anti-HCV and 28 patients $(1.53 \%)$ had anti-HDV while 1 patient $(0.055 \%)$ had positive antiHIV. The mean age of the patients with positive anti-HDV was $53.16 \pm 15.46$ and 12 of these (42.9\%) were female and $16(57.1 \%)$ were male. Fifteen HDV positive patients were given peginterferon and 10 patients had relapse and 4 patients had hepatocellular cancer during the follow-up. A patient died due to the quick progression of the disease after deciding upon transplantation.

Conclusion: Patients should also be scanned for hepatitis C, D and HIV in the presence of hepatitis B infection and the patient should be followed up and treated accordingly if coinfection is detected. Keywords: Hepatitis B, hepatitis C, hepatitis D, HIV, coinfection
\end{abstract}

ÖZ

Amaç: Hepatit B enfeksiyonu, hepatitis $C$ virüs (HCV), HDV, insan bağışıklık yetmezliği virüsü (HIV) enfeksiyonu varlığında daha hızlı ve progresif seyreder. Bu çalışmada hepatit B yüzey antijen ( $\mathrm{HBsAg}$ ) pozitifliği saptanan hastalarda anti-HCV, anti-HDV, anti-HIV sıklığının belirlenmesi ve anti-HDV pozitifliği saptanan hastaların irdelenmesi amaçlanmıştır.

Gereç ve Yöntemler: Veriler hepatit B hasta takip dosyaları ve hastane otomasyon sistemi üzerinden taranarak elde edildi. Tanımlayıcı veriler sayı ve yüzde (\%) olarak belirtildi.

Bulgular: HBsAg pozitif 1829 hastanın yaş ortalaması $42,65 \pm 14,83$ (7-95) olup 1099'u $(\% 60,1)$ erkek, 730'u $(\% 39,9)$ kadındı. Thirty anti-HCV $(\% 1,64), 28(\% 1,53)$ anti-HDV, $1 \quad(\% 0,055)$ anti-HIV pozitifliği saptandı. Anti-HDV pozitif olan hastaların yaş ortalaması; $53,16 \pm 15,46$ olup 12 'si $(\% 42,9)$ kadın, 16 'sı $(\% 57,1)$ erkekti. HDV pozitif 15 hastaya peginterferon verilmiş olup takipte 10 hastada relaps, 4 hastada hepatoselüler kanser gelişti. Nakil kararı verilmiş olan bir hastada, hastalık hızlı progresyon gösterdiğinden hasta kaybedildi.

Sonuç: Hepatit B enfeksiyonu varlı̆ında hastalar hepatit C, D ve HIV yönünden de taranmalı ve koenfeksiyon saptandığında, hasta buna yönelik de takip ve tedavi edilmelidir.

Anahtar Kelimeler: Hepatit B, hepatit C, hepatit D, HIV, koenfeksiyon

Kepenek Kurt E, Bulut R, Kandemir B, Erayman I, Bitirgen M, Esenkaya Taşbent F. Investigating Hepatitis C, D and HIV Prevalance in Cases with Positive Hepatitis B Virus Antigen in a Tertiary Hospital and Examining Anti-HDV Positive Cases. Viral Hepat J. 2021;27:31-35. 


\section{Introduction}

With an epidemiology affected by different factors such as vaccine and immigration, hepatitis $B$ virus (HBV) infection is a global public health problem (1). The number of HBV-infected individuals around the world is estimated as nearly two billion. Many people die due to HBV-related diseases every year. A positive change is observed globally in hepatitis B surface antigen ( $\mathrm{HBsAg}$ ) positivity. Thus, while global number of chronic HBV cases was considered to be around $\mathbf{4 0 0}$ million until the last few years, this number is estimated to decrease approximately down to 240-257 million. Coinfection of other viral factors may also accompany HBV (2). Delta hepatitis or HDV was first discovered by Rizzetto et al. (3) in 1977. HDV can be seen as a coinfection with HBV or a superinfection in individuals infected with HBV (4). HDV can not form its own envelope protein since it is a defective hepatotropic virus affecting patients only with HBV infection and needs HBV for virion production and disease formation $(3,5)$. Although seen rarely among chronic viral hepatitis, chronic delta hepatitis is the type with the severest course. HDV causes a more severe course in hepatitis B infection-caused acute and chronic liver diseases and also a significant increase in becoming chronic (6). These two viruses share the same transmission ways as parenteral, sexual and maternal (3). Nearly $5 \%$ of HBV carriers are also HDV-infected (7). Although the prevalence changes according to regions, nearly 15-20 million people are estimated to be infected with HDV around the world (8).

In patients with chronic HBV infection, HCV coinfection fastens liver disease progression and increases hepatocellular carcinoma $(\mathrm{HCC})$ risk (1). Although hepatitis $B$ and $C$ viruses have different life cycles and gene sequences, they follow the same common path in disease progression. Anti-HCV positivity is 3-20\% in $\mathrm{HBsAg}$ positive individuals and $\mathrm{HBsAg}$ positivity is $2-10 \%$ in anti-HCV positive individuals (9). HBV and HCV concurrence was shown to be high especially in places where HBV and HCV infections are endemic and also in intravenous drug addicted individuals (10). $\mathrm{HCV}$ coinfection rate was found as $10-15 \%$ in chronic HBV patients (2).

Nearly 36.7 million individuals have human immunodeficiency virus (HIV) worldwide and 2.7 million of these cases are coinfected with HBV (2). Liver fibrosis progression, cirrhosis and HCC risk increases in patients with HIV/HBV coinfection (1). The aim of this study was to determine anti-HCV, anti-HDV and anti-HIV prevalence in HBsAg (+) positive patients and to evaluate patients with antiHDV positivity.

\section{Materials and Methods}

After taking the consent of university Ethics Board for the study (approval number: 2019/1921), the demographic characteristics and
anti-HCV, anti-HDV and anti-HIV results of the patients detected to have HBsAg positive result and aspartate aminotransferase (AST), alanine aminotransferase (ALT), hepatitis $B$ e antigen ( $\mathrm{HBeAg})$, anti$\mathrm{HBe}, \mathrm{HBV}-\mathrm{DNA}$, HDV-RNA values, biopsy results, treatments and prognoses of patients detected to have anti-HDV (+) between 2000 and 2018 in our clinic were scanned through hepatitis B patient follow-up files and hospital automation system and were analyzed through recording on Excel form.

\section{Statistical Analysis}

Data were stated in number, percentage (\%), mean, median and standard deviation.

\section{Results}

Mean age of a total of $1829 \mathrm{HBsAg}(+)$ patients was $42.65 \pm 14.83$ (7-95) and 1099 of them (60.1\%) were male and 730 (39.9\%) were female. Anti-HCV, anti-HDV and anti-HIV were checked in all patients and their test results were provided on Table 1

Mean age of 28 patients detected to have both HBsAg and anti-HDV positive was 53.16 \pm 15.46 (minimum: 29 , maximum: 72 ) and 12 of these were female $(42.9 \%)$ and 16 were male $(57.1 \%)$. Mean HBV-DNA of the patients was $64.4 \times 10^{6} \mathrm{copy} / \mathrm{mL}$ (minimum: 0, maximum: $288.2 \times 10^{6} \mathrm{copy} / \mathrm{mL}$ ) and ALT (minimum: $15 \mathrm{u} / \mathrm{Lt}$, maximum: $1650 \mathrm{u} / \mathrm{Lt}$ ) was detected in 16 patients and high AST was detected in 14 patients (minimum: $17 \mathrm{u} / \mathrm{Lt}$ maximum; 917 u/Lt). Initial HDV-RNA was negative for two patients and mean HDV-RNA of the other eight patients with accessible HDV-RNA information was found as $40 \times 10^{6} \mathrm{copy} / \mathrm{mL}$ (minimum: 1240, maximum: $18.2 \times 10^{6}$ copy $/ \mathrm{mL}$ ). Biopsy could not be performed in four patients since it was contraindicated and the biopsy results of 21 patients were reachable. Epidemiological data, biopsy results and laboratory findings of the patients detected to have positive anti-HDV were shown in Table 2. Treatment information of fifteen patients was reachable and it was found that peginterferon-alpha (PeglFN- $\alpha$ ) treatment was given to these patients for 1 year. 10 patients had relapse and 4 patients had HCC in the follow-ups. A patient whose transplantation was decided upon died due to the quick progression of the disease. As anti-HBc IgM was detected negative in all patients, they were all considered to have superinfection. Delta antigen results were reachable for 14 cases detected to have positive anti-HDV and 12 of these results were negative and 2 were positive. Anti-HCV and anti-HIV positivity wasn't detected in any of these patients.

\section{Discussion}

Increased HCC risk was validated and shown in the epidemiological studies made in patients with HBV/HCV coinfection $(11,12)$. While HCC risk was 6.4 for 100 patients with coinfection

\begin{tabular}{|l|l|l|l|}
\hline Table 1. Hepatitis C, D and HIV* seroprevalence in HBsAg** $(+)$ patients & Percentage (\%) \\
\hline Serology & Antibody studied & Number & 1.64 \\
\hline Hepatitis C $(n=1829)$ & Anti-HCV*** & 30 & 1.53 \\
\hline Hepatitis D $(n=1829)$ & Anti-HDV**** & 28 & 0.055 \\
\hline HIV ( $n=1829)$ & Anti-HIV & 1 & \\
\hline *HIV: Human immunodeficiency virus, ${ }^{* * H B s A g: ~ H e p a t i t i s ~ B ~ s u r f a c e ~ a n t i g e n, ~}{ }^{* * *}$ Anti-HCV: Anti-hepatitis C virus, ****Anti-HDV: Anti-hepatitis D virus
\end{tabular}




\begin{tabular}{|c|c|}
\hline Age (years) mean & $53.16 \pm 15.46$ \\
\hline Gender (female/male) (n, \%) & $12(42.9), 16(57.1)$ \\
\hline $\mathrm{HBeAg}^{* *}$ anti-HBe***(-) (n=28) (\%) & $3(10.7)$ \\
\hline HBeAg (+) anti-HBe (-) (n=28) (\%) & $2(7.2)$ \\
\hline Mean $\mathrm{ALT}^{* * * * *}(\mathrm{n}=28)$ & $144.6 \mathrm{u} / \mathrm{Lt}$ \\
\hline Mean HDV-RNA ( $n=8)$ & $40 \times 10^{6} \mathrm{copy} / \mathrm{mL}$ \\
\hline $\begin{array}{l}\text { Biopsy result stage } 0-2 \\
(n=21)(\%) 3-4 \\
5\end{array}$ & $\begin{array}{l}13(61.9) \\
7(33.3) \\
1(4.8)\end{array}$ \\
\hline
\end{tabular}

in another study, it was detected as 2 in HBV mono infection and as 3.7 in HCV mono infection (13). In a study made in Egypt, HBV/ $\mathrm{HCV}$ coinfection prevalence was reported as $0.7 \%$ (14). Coinfection rate was detected as $5.8 \%$ in another study made in USA (15). Inci et al. (16) evaluated 1339 CHD patients in a study made in Istanbul in 2012 and detected anti-HCV positive in 26 (1.9\%) patients. Anti-HCV positivity was detected in $1.64 \%$ of HBsAg (+) patients in our study. In general, this rate is lower than other studies and this condition may be related to the attention paid to sterilization and disinfection in hemodialysis and other invasive operations, use of disposable injectors and scanning of hepatitis analyses before blood and blood products transfusion.

Değertekin et al. (17) evaluated studies on delta hepatitis between 1980 and 2005 and showed that there was a decrease in delta hepatitis in Turkey between 1980 and 2005 (4.1\% and 2.9\%) and delta hepatitis was mainly a problem in Southeastern region. Delta positivity rate was found 20\% (5961 cases) in chronic HBV cases and $32.5 \%$ in cirrhotic cases in the same study and it was detected as 3\% in 1416 acute viral hepatitis cases, 8.1\% in 766 acute HBV infections, $4.9 \%$ in 6613 inactive HBV carrier cases, $32.52 \%$ in cirrhosis patients $(11,264$ cases) and as $23 \%$ in HCC cases (17). In the Bus Project made by Viral Hepatitis Society in 2009, positive results were acquired in 43 cases (2.39\%) when anti-delta immunoglobulin G (anti-HDV lgG) was also checked in 1805 HBsAg positive individuals among a total of 29960 individuals aged between 0 and 103 (18). In the study made by Eser-Karadağ (19) in Elazığ between 2017 and 2019, anti-HDV positivity was detected in $8.8 \%$ out of 455 chronic HBV infection diagnosed patients. Güdücüoğlu et al. (20) found anti-HDV positivity in the serums of 36 out of $184 \mathrm{HBsAg}$ positive soldiers (19.5\%) in Van Military Hospital in 2006. Prevalence of HDV coinfection (antiHDV IgM positive in 3 patients) in addition to acute HBV infection (anti-HBC IgM positive in 39 patients) was 7.69\%. Prevalence of HDV superinfection (anti-HDV total "IgM+lgG" positive in 145 patients) prevalence in addition to chronic HBV infection (anti-HBc total "IgM+lgG" positive in 36 patients) was $24.8 \%$ (20). In a study covering some cities of Eastern Anatolia including Van, antiHDV was found positive in 55 out of $955 \mathrm{HBsAg}$ positive cases (5.8\%) (21). Doğan et al. (22) found anti-HDV prevalence as 7.3\% in patients with chronic HBV infection in Ağrı in 2012. Kart Yaşar et al. (23) found positive anti-HDV results in 49 out of $692 \mathrm{HBsAg}$ positive cases in Istanbul (7\%). Izmirli et al. (24) found anti-HDV positive in $4.5 \%$ of $\mathrm{HBsAg}$ positive cases and $4.4 \%$ of chronic hepatitis $\mathrm{B}(\mathrm{CHB})$ patients in the study they made in Istanbul in 2011. Anti-HDV positivity was detected in $1.9 \%$ out of 1829 $\mathrm{HBsAg}$ positive patients in Konya region in our study. This rate was found lower compared to other studies made in different regions of our country at different times. Since HDV occurs in the presence of $\mathrm{HBV}$, this condition may be related to hepatitis B vaccination condition, application of injection and other invasive operations in sterile conditions, improvement of socioeconomic condition and public training on hepatitis $B$ and vaccine in our region.

It was reported that HDV infection could affect all age groups (24). In a study made in our country and covering central regions of Black Sea including Samsun, the mean age of HDV positive patients was found 45.63 years (16-74 years) higher (25). Mean age of HDV positive patients was $53.16 \pm 15.46$ years higher in our study and this condition may be related to the fact that young individuals are vaccinated in our country since hepatitis B was included in routine vaccine program in 1998.

Although hepatitis $D$ positivity is not statistically significant in literature, it was found to be more common in males (26). Parlak et al. (27) also found this infection more common in males (66\%). $57.1 \%$ of the patients with positive anti-HDV were males in our study and this may be explained by higher rate of risky behaviors in males in line with literature.

HDV infection suppresses HBV replication in general and $\mathrm{HBeAg}$ negative, anti-HBe positive $\mathrm{CHB}$ and low titrated HBV causes DNA positivity (27). Mean HBV-DNA of the patients was $64.4 \times 10^{6} \mathrm{copy} / \mathrm{mL}$ (minimum: 0, maximum: $288.2 \times 10^{6} \mathrm{copy} / \mathrm{mL}$ ) 
in our study. In the study by Parlak et al. (27), mean HBV-DNA was found $3449908.09 \pm 29928971.38 \mathrm{IU} / \mathrm{mL}$ in $\mathrm{HBsAg}$ positive patients.

Izmirli et al. (24) found superinfection rate more than coinfection. Superinfection was found in all patients in our study.

EASL 2017 suggests PeglFN- $\alpha$ for minimum 48 weeks in patients with HDV/HBV coinfected compensated liver disease. PegIFN- $\alpha$ is the only drug with proven antiviral efficiency against chronic HDV infection now (28). Treatment information of 15 patients could be reached in our study and it was determined that PegIFN- $\alpha$ treatment was provided for 48 weeks in these patients. Ten patients had relapse and 4 patients had HCC formation and one patient whose transplantation was decided died due to the quick progression of the disease.

Course of HBV infection is faster in individuals coinfected with HIV. Cirrhosis, final stage liver disease and/or HCC formation may be much faster. HBV is observed in $5-10 \%$ of HIV infected individuals globally. Although effective antiretroviral treatment (ART) decelerates progression to cirrhosis, it is interesting that the risk remain high when compared to individuals without coinfection (29). Positive anti-HIV was detected in $0.055 \%$ of the patients in our study. Although a HBsAg positive patient was anti-HIV negative at the beginning, the result became anti-HIV positive during the follow-up. This condition brings along the question "Should antiHIV be checked at certain intervals in individuals with positive HBsAg?" due to the similarity of transmission ways for HBV and HIV.

Regardless of CD4 cell count, ART should be started in all patients with HIV-HBV coinfection (1). It is suggested that HIV/ HBV coinfected and ART scheme should cover two drugs affected on the two viruses (30). Tenofovir is the most important antiviral agent effective for both HIV and HBV in HIV/HBV coinfection today. Although a HBsAg positive had a negative anti-HIV test result at the beginning in our study, anti-HIV result became positive in the follow-up and tenofovir containing ART was started after a detailed examination.

\section{Conclusion}

HCV, HDV and HIV infection rates were found low in hepatitis B diagnosed cases in our region in our study. Due to similar transmission ways and since the liver damage would be high in the presence of coinfection, HCV and HDV should be scanned in HBV presence and treated in a suitable way if detected positive. Although PegIFN is used as the only agent in hepatitis $D$ in our country, new treatment agents are needed for HDV treatment since the disease may relapse.

\section{Ethics}

Ethics Committee Approval: Ethics committee approval for this study was obtained from the Necmettin Erbakan University, Meram Faculty of Medicine, Non-Invasive Clinical Studies Ethics Committee (approval number: 2019/1921, date: 21.06.2019).

Informed Consent: It wasn't obtained.

Peer-review: Externally and internally peer-reviewed.

\section{Authorship Contributions}

Surgical and Medical Practices: E.K.K., Consept: E.K.K., I.E., B.K., Desing: E.K.K., I.E., B.K., Data Collection or Processing: E.K.K., R.B., F.E.T., Analysis or Interpretation: E.K.K., R.B., Literature Search: E.K.K., R.B., I.E., M.B., Writing: E.K.K., B.K., I.E., M.B.

Conflict of Interest: The authors of this article declare that they have no conflict of interest.

Financial Disclosure: The authors declare that this study has not received any financial support.

\section{References}

1. European Association for the Study of the Liver. EASL 2017 Clinical Practice Guidelines on the management of hepatitis B virus infection. Journal of Hepatology. 2017;67:370-398.

2. Tosun S. Epidemiology of Viral Hepatitis B in the world and Turkey. In: Güner R, Tabak F, (eds.), Viral Hepatitis 2018. The 1. Print. Istanbul Medical Press: Istanbul; 2018. p. 13-32.

3. Rizzetto M, Canese MG, Aricò S, Crivelli O, Trepo C, Bonino F, Verme G. Immunofluorescence detection of new antigen-antibody system (delta/anti-delta) associated to hepatitis B virus in liver and in serum of HBsAg carriers. Gut. 1977;18:997-1003.

4. Romeo R. Role of the hepatitis Delta virus on the pathogenesis of hepatic cirrhosis and hepatocellular carcinoma. Recent advances. Recenti Prog Med. 2010;101:52-56

5. Çelen MK. Hepatitis Delta Virus and Immunopathogenesis. In Güner R, Tabak F (eds.), Viral Hepatitis 2018. The 1. Print. Istanbul Medical Press: Istanbul; 2018. p. 379-381.

6. Çelen MK. The natural course of HDV infection. In: Balık I, Tabak F, (eds.), Viral Hepatit 2009, Viral Hepatitis Society. Express Print: Istanbul; 2009. p. 181-186.

7. Abbas Z, Jafri W, Raza S. Hepatitis D: Scenario in the Asia-Pacific region. World J Gastroenterol. 2010;16:554-562.

8. Wedemeyer $\mathrm{H}$, Manns MP. Epidemiology, pathogenesis and management of hepatitis D: update and challenges ahead. Nat Rev Gastroenterol Hepatol. 2010;7:31-40.

9. Liu Z, Hou J. Hepatitis B virus and hepatitis $C$ virus dual infection. Int J Med Sci. 2006;3:57-62.

10. Chu CJ, Lee SD. Hepatitis B virus/hepatitis C virus coinfection: epidemiology, clinical features, viral interactions and treatment. J Gastroenterol Hepatol. 2008;23:512-520.

11. Cho LY, Yang JJ, Ko KP, Park B, Shin A, Lim MK, Oh JK, Park S, Kim YJ, Shin HR, Yoo KY, Park SK. Coinfection of hepatitis B and $C$ viruses and risk of hepatocellular carcinoma: systematic review and meta-analysis. Int J Cancer. 2011;128:176-184.

12. Shi J, Zhu L, Liu S, Xie WF. A meta-analysis of case-control studies on the combined effect of hepatitis $\mathrm{B}$ and $\mathrm{C}$ virus infections in causing hepatocellular carcinoma in China. $\mathrm{Br} \mathrm{J}$ Cancer. 2005:92:607-612

13. Chiaramonte $M$, Stroffolini $T$, Vian $A$, Stazi MA, Floreani $A$, Lorenzoni U, Lobello S, Farinati F, Naccarato R. Rate of incidence of hepatocellular carcinoma in patients with compensated viral cirrrhosis. Cancer. 1999;85:2132-2137.

14. Mekky MA, Nasr AM, Saleh MA, Wasif NK, Khalaf M, Aboalam $H$, Haredy M. Virologic and histologic characterisation of dual hepatitis B and C co-infection in Egyptian patients. Arab J Gastroenterol. 2013;14:143-147.

15. Bini EJ, Perumalswami PV. Hepatitis virus infection among American patients with chronic hepatitis C virus infection: prevalence, racial/ethnic differences, and viral intercations. Hepatology. 2010;51:759-766. 
16. Inci A, Fincanci M, Müderrisoğlu C. Investigation of Anti-Hepatitis Delta Virus and Anti-Hepatitis C Virus in Patients with Hepatitis B Virus Infection. Istanbul Med J. 2013;14:109-111.

17. Değertekin $\mathrm{H}$, Yalçin $\mathrm{K}$, Yakut M. The prevalence of hepatitis delta virus infection in acute and chronic liver diseases in Turkey: an analysis of clinical studies. Turk J Gastroenterol. 2006;17:25-34.

18. Örmeci N, Balık I, Tabak F, et al. HDV results in HBsAg positive people in the cities circulating by bus, X. National Viral Hepatitis Congress; Antalya; 2010. S173.

19. Eser-Karadağ G. Prevalence of hepatitis delta in chronic hepatitis B patients. Klimik J. 2019;32:281-284.

20. Güdücüoğlu H, Altunbaş $S$, Bozkurt $H$, Baykal $S$, Berktaş $M$. The investigation of Delta antibody at $\mathrm{HBsAg}$ positive soldier in Van Military Hospital. Van Medical J. 2006;13:118-120.

21. Kurtoğlu MG, Üstün $C$, Bozkurt H, Tuncer O, Berktaş M. Hepatitis D Virus Seroprevalence Determined During Periods of Hepatitis B Virus Infections In Eastern Turkey. Viral Hepatit J. 2009;14:27-32.

22. Doğan $M$, Güneş $H$, Mete R, Taş T, Mengeloğlu FZ, Küçükbayrak A. Prevalence of anti-HDV and HDAg in patients with chronic hepatitis B. Dicle Med J. 2013;40:50-53.

23. Kart Yaşar K, Pehlivanoğlu F, Şengöz G. Seroprevalences of Hepatitis B Virus and Hepatitis D Virus Infections Detected in Our Laboratory within Eight-Month Period. Viral Hepatit J. 2011:17:2226.
24. Izmirli S, Çelik DG, Güngördü Z, Ziver T, Aslan M, Sarıbaş S, Calışkan R, Yüksel P, Kocazeybek B. Seroprevalence of Hepatitis Delta Infection: Retrospective-Based Seroepidemiologic Assessment. Flora. 2011;16:120-126.

25. Karadağ A, Yılmaz H, Gören I, Acuner IC, Eroğlu C, Günaydın M. Defining the Delta Virus Positivity in Hepatitis B Virus Infections. Viral Hepatit J. 2014;20:64-66.

26. Değertekin H, Tabak F, Balık I, Tekeli E. Epidemiology of HDV Infection. Viral Hepatitis 2007. The 1. Print, Istanbul, Viral Hepatitis Society, 2007.p.256-262.

27. Parlak E, Ertürk A, Parlak M, Koşan Z, Albayrak A, Özkurt Z, Özden K, Erol S. Assessment of Patients with Hepatitis D. Viral Hepatit J. 2015;21:80-84.

28. Heidrich B, Yurdaydın C, Kabaçam G, Ratsch BA, Zachou K, Bremer B, Dalekos GN, Erhardt A, Tabak F, Yalcin K, Gürel S, Zeuzem S, Cornberg M, Bock CT, Manns MP, Wedemeyer H; HIDIT-1 Study Group. Late HDV RNA relapse after peginterferon alpha-based therapy of chronic hepatitis delta. Hepatology. 2014;60:87-97.

29. T.C. Ministry of Health. General Directorate of Public Health. Management of HIV and Hepatitis B/Hepatitis C Coinfections. HIV/AIDS Diagnosis and Treatment Guidelines; Ankara, 2019. p. 209-211.

30. Karaosmanoğlu HK. HIV and HBV Coinfection. Güner R, Tabak F, (eds.), Viral Hepatitis 2018. The 1. Print. Istanbul Medical Press: Istanbul; 2018. p. 459-465. 